\title{
Abdominal damage control surgery and reconstruction: world society of emergency surgery position paper
}

\author{
Laura Godat, Leslie Kobayashi, Todd Costantini and Raul Coimbra*
}

\begin{abstract}
Damage control laparotomy was first described by Dr. Harlan Stone in 1983 when he suggested that patients with severe trauma should have their primary procedures abbreviated when coagulopathy was encountered. He recommended temporizing patients with abdominal packing and temporary closure to allow restoration of normal physiology prior to returning to the operating room for definitive repair. The term damage control in the trauma setting was coined by Rotondo et al., in 1993. Studies in subsequent years have validated this technique by demonstrating decreased mortality and immediate post-operative complications. The indications for damage control laparotomy have evolved to encompass abdominal compartment syndrome, abdominal sepsis, vascular and acute care surgery cases. The perioperative critical care provided to these patients, including sedation, paralysis, nutrition, and fluid management strategies may improve closure rates and recovery. In the rare cases of inability to primarily close the abdomen, there are a number of reconstructive strategies that may be used in the acute and chronic phases of abdominal closure.
\end{abstract}

Keywords: Trauma, Damage control, Abdominal compartment syndrome, Temporary abdominal closure

\section{Introduction}

The bloody lethal triad of hypothermia, acidosis, and coagulopathy has been the nemesis of trauma surgeons for decades. Many advances in the field of trauma have evolved around prevention and treatment of this clinical scenario. One useful technique is damage control laparotomy (DCL). DCL has 3 stages, an abbreviated initial operative procedure with temporary abdominal closure (TAC); continued resuscitation and management of physiologic and acid-base derangements, and definitive treatment and closure.

The first stage in DCL is control of hemorrhage and contamination followed by use of a TAC strategy [1]. The optimal TAC strategy should prevent evisceration, evacuate fluid, allow access to the abdominal cavity, and allow for expansion in order to prevent abdominal compartment syndrome (ACS) [2-4]. The second stage of DCL involves continuation of resuscitation, which should include

\footnotetext{
* Correspondence: rcoimbra@ucsd.edu
Division of Trauma, Surgical Critical Care, and Burns, University of California,

* Correspondence: rcoimbra@ucsd.edu
Division of Trauma, Surgical Critical Care, and Burns, University of California, San Diego, 200 West Arbor Dr., \#8896, San Diego CA 92103-8896, United States of America
}

(c) 2013 Godat et al.; licensee BioMed Central Ltd. This is an Open Access article distributed under the terms of the Creative Commons Attribution License (http://creativecommons.org/licenses/by/2.0), which permits unrestricted use, distribution, and reproduction in any medium, provided the original work is properly cited. The Creative Commons Public Domain Dedication waiver (http://creativecommons.org/publicdomain/zero/1.0/) applies to the data made available in this article, unless otherwise stated.

judicious fluid administration with aggressive correction of coagulopathy, acidosis, and hypothermia. Additional management may include paralysis, early enteral nutrition, and diuresis. Lastly, once normal physiology has been restored, the patient should return to the operating room for definitive repair of injuries, followed by abdominal wall closure with reconstruction if possible in the same or in subsequent operative interventions.

DCL has been associated with improved outcomes and decreased mortality in severely injured trauma patients $[5,6]$. Because of this, DCL indications have been expanded to include abdominal sepsis, ACS, and prolonged or extensive elective surgery. This is a review of the current literature on DCL including recommendations regarding the indications for $\mathrm{DCL}$, techniques of TAC, intensive care unit (ICU) management, and abdominal closure with reconstruction.

To our knowledge no randomized controlled trials (RCT) exist for the use of DCL, although there are many retrospective reviews and prospective observational trials demonstrating improved outcomes in both trauma and acute care surgery populations $[2,7]$. 


\section{Review}

Indications

The decision to switch from definitive treatment to damage control should be made early, ideally prior to entering the operative suite, as this has been associated with improved mortality [7]. In trauma patients, relative pre-operative indications for DCL include systolic blood pressure $(\mathrm{SBP})<90 \mathrm{mmHg}$ with penetrating torso, blunt abdominal, or severe pelvic trauma, and the need for resuscitative thoracotomy [1]. Other Emergency Department (ED) variables associated with increased use of DCL include SBP $<60 \mathrm{mmHg}$, hypothermia, inappropriate bradycardia, and $\mathrm{pH}$ of $<7.2[8,9]$. Intraoperative indications for DCL in trauma patients include "non-surgical" bleeding, $\mathrm{pH} \leq 7.18$, temperature $\leq 33^{\circ} \mathrm{C}$, transfusion of $\geq 10$ units of blood, total fluid replacement $>12 \mathrm{~L}$, and estimated blood losses of $\geq 5 \mathrm{~L}[5,6]$. Platelet count, PT, aPTT, fibrinogen levels and thromboelastography findings can also be used to guide decision making if available [8].

In addition to the above indications, patients at high risk for ACS should be left open prophylactically at the time of laparotomy $[10,11]$. This includes patients requiring large volume resuscitation ( $>15 \mathrm{~L}$ or 10 Units of PRBCs), those with evidence of visceral edema, peak inspiratory pressures $>40$, or intra-abdominal pressure (IAP) $>21$ during attempted closure [12-16]. Patients with IAP $>12 \mathrm{mmHg}$ are considered to have intra-abdominal hypertension (IAH) which is graded from I to IV (Table 1). ACS is a syndrome of organ dysfunction; cardiac, renal or pulmonary associated with elevated IAP and reduced intraabdominal blood flow [17]. If organ failure has developed patients require emergent decompressive laparotomy or revision of their TAC $[12,13,17]$.

DCL has also been beneficial in general surgery patients with severe abdominal sepsis, including those with diverticulitis or necrotizing pancreatitis who require serial debridement as well as those with significant blood loss $[12,18-22]$. Patients with mesenteric ischemia or venous occlusive disease who require staged laparotomies due to questionable bowel viability may also benefit from DCL [23]. Advanced age is not a contraindication to DCL as good outcomes have been seen in the elderly [24,25].

Table 1 Grades of intra-abdominal hypertension

\begin{tabular}{ccc}
\hline Grade & *IAP & Organ failure \\
\hline I & $12-15$ & Absent \\
II & $16-20$ & Absent \\
III & $21-25$ & Absent \\
IV & $>25$ & Absent \\
${ }^{* *}$ ACS & $>20$ & Present \\
\hline
\end{tabular}

*IAP = Intra-abdominal pressure.

${ }^{* *} \mathrm{ACS}=$ Abdominal Compartment Syndrome.
Despite improvements in mortality seen in severely injured patients treated with DCL, there is evidence to suggest that it may worsen outcomes in patients who do not meet the indications described above [26]. A retrospective review of over 600 cases, found that low risk patients, identified as those with absence of shock, severe head or combined abdominal injury (Abbreviated Injury Scale $<3$ ) had significantly higher rates of infections, organ failure, pulmonary and bowel related complications compared to similar patients closed at the time of their first procedure [27].

\section{Temporary abdominal closure methods}

Because the abdomen is left open at DCL, the resultant wound requires a dressing or TAC. The ideal TAC should be easily and quickly applied, allow room for expansion, limit contamination, decrease bowel edema, protect the viscera, fascia and skin from damage, evacuate fluids, prevent adhesions, minimize loss of domain and be cost effective. The TAC should be easily changed, result in a high rate of closure and be associated with a low rate of complications, particularly enterocutaneous fistula (EC fistula) and mortality (Table 2).

The first series of DCLs used towel clips or running sutures for closure of the skin or fascia to provide a tamponade effect with peritoneal packing [5]. However, this type of closure frequently resulted in ACS $[2,14,28,29]$, and it is no longer recommended. The next generation TACs were performed using a silo or Bogota bag where a non-permeable barrier; IV bag, bowel bag, steri-Drape or silastic cloth was sutured to the skin or fascia. Advantages are prevention of desiccation, swift application, ability to visualize the bowel and low cost. However, disadvantages include damage to the skin, loss of domain, and lack of effective fluid removal $[2,30]$. Primary closure rates vary from $12.2-82 \%$ [31,32]. EC fistula rates are generally low, reported at $0-14.4 \%$ [14,31-36] however ACS rates range as high as $33 \%[11,33,36]$. This method has also largely been abandoned.

Vacuum assisted closure (VAC) devices are most commonly used today. Barker et al., coined the term "vacuum pack" (VP) in 1995; describing a 3 layer TAC;

Table 2 Methods of temporary abdominal closure (TAC)

\begin{tabular}{cccc}
\hline Method of TAC & $\begin{array}{c}\text { Primary } \\
\text { closure rate }\end{array}$ & $\begin{array}{c}\text { Mortality } \\
\text { rate }\end{array}$ & $\begin{array}{c}\text { Enterocutaneous } \\
\text { fistula rate }\end{array}$ \\
\hline $\begin{array}{c}\text { Bogota Bag/Silo } \\
{[14,31-36]}\end{array}$ & $12.2-82 \%$ & $19-58.4 \%$ & $0-14.4 \%$ \\
$\begin{array}{c}\text { Mesh/Wittman Patch } \\
{[19,42,51,54,55,58]}\end{array}$ & $18-93 \%$ & $7.7-43 \%$ & $0-26 \%$ \\
$\begin{array}{c}\text { Vacuum Assisted } \\
\text { Closure Device } \\
{[38,39,41,44,45]}\end{array}$ & $31-100 \%$ & $14-44 \%$ & $1.2-15 \%$ \\
\hline
\end{tabular}


consisting of a fenestrated polyethylene sheet between the abdominal viscera and parietal peritoneum, followed by a moist towel with closed suction drains covered with an occlusive adhesive drape [37]. This method is inexpensive, easily applied and changed, protects the viscera, prevents adhesions, removes exudate and prevents some loss of domain [2,37]. Commercially prepared negative pressure dressings are available and function similar to the VP. These are the V.A.C.@Abdominal Dressing system and the Abthera $^{\mathrm{Tw}}$ system. Both devices use three layers. The inner layer is a plastic covered sponge that is inserted into the gutters to protect the viscera and facilitate fluid removal, this is followed by a Micro or Macroporous sponge covered by an occlusive dressing that is attached to suction [38-40]. These techniques have been associated with a 31$100 \%$ primary closure rate [38-42]. EC fistula rates vary in the literature from $1.2 \%-15 \%$ [41-45], but are generally low. A prospective comparison of these two systems showed higher 30-day primary fascial closure rates and lower 30-day all-cause mortality with the Abthera ${ }^{\text {Twx }}$ system compared to the Barker VP [46].

Lastly, there are multiple TACs that interpose a graft material between the fascial edges. This can be absorbable such as vicryl or biologic mesh, non-absorbable such as polypropylene (PPE) or expanded polytetrafluoroethylene (ePTFE), or a Wittman patch. The material is initially applied loosely to allow for bowel expansion and prevent ACS. Serial examinations of the wound at the bedside or in the operating room must be done and the mesh is pleated or refastened to gradually pull the fascial edges together [47-49]. The primary benefit of these systems is their ability to maintain and recover fascial domain. Drawbacks include damage to the fascia, inability to prevent adhesions and difficulty with fluid management. EC fistula rates vary with type of graft material; as high as $7-26 \%$ with non-absorbable mesh [42,50-52], followed by 4.6$18 \%$ with absorbable mesh $[49,53,54]$, and the Wittman patch which has the lowest reported rates of $0-4.2 \%$ [55-58]. Risk of ECF is reduced if omentum is interposed between the mesh and bowel [52]. Primary closure has been reported as late as $>50$ days after the initial damage control operation [49]. ACS rates associated with interposition grafts are seldom sited in the literature; most that did reported no incidences $[48,53,54]$.

\section{Resuscitation}

The second stage of DCL is resuscitation focused on correction of physiologic derangements, acidosis, oxygen debt, coagulopathy and hypothermia [1]. Hemodynamic derangements due to hypovolemic shock should be reversed as quickly as possible with volume resuscitation. However, over use of crystalloids can result in third spacing worsening bowel edema, anastomotic leaks, ACS and multi-organ failure [59,60]. Accordingly, the use of massive transfusion protocols (MTP) has been recommended for DCL patients [60-62]. MTP's advocate using blood transfusion earlier in resuscitation, using blood and blood products instead of crystalloid or colloid, and the infusion of red cells, plasma, and platelets in a 1:1:1 ratio. There is evidence to suggest that MTP's and use of 1:1:1 transfusion ratios results in lower overall fluid requirements, blood utilization, and possibly improved mortality in patients with massive blood loss, severe injury and severe physiological derangements, such as are encountered in DCL patients $[63,64]$. In addition, fluid resuscitation should be guided by hemodynamic parameters such as stroke volume variance or pulse pressure differentials and central venous or left atrial pressures. Improved fluid management may decrease the incidence of ACS and promote early fascial closure [28,65,66]. There is also some evidence that the use of hypertonic fluids in the postoperative period may decrease time to primary closure and improve the primary closure rate [67]. Patients should be monitored for development of ACS and if exhibiting symptoms, the TAC should be removed and replaced with a looser device immediately [2].

Prophylactic antibiotics should be administered preoperatively when possible as infection rates increase if given intra or post operatively [68], and duration should be no longer than 24 hours [69].

It has been proposed that neuromuscular blockade (NMB) can help prevent retraction of the fascial edge and improve closure rates. However, the current evidence comparing NMB to simple sedation is equivocal $[44,70]$. Similarly diuresis is often suggested as a means to decrease bowel edema and facilitate fascial closure once patients have been resuscitated; however, there is no convincing data to suggest use of diuretics improves the rate or time to closure [71].

Nutrition is known to be a key component to the recovery of patients following severe injury. There are no RCT's of enteral nutrition in patients with an open abdomen; however multiple retrospective reviews and one prospective cohort study demonstrate safety of enteral nutrition within 36 hours to 4 days of DCL [72-75]. Two studies have demonstrated increased rates of fascial closure [72,73], and 3 demonstrated decreased infectious complications $[72,73,75]$ with early enteral nutrition.

\section{Closure and abdominal wall reconstruction}

Initial return to the operating room should occur as soon as normal physiology has been restored and can vary from $6-72$ hours from the time of the primary procedure [2]. Patients should also be taken back to the operating room if there is evidence of surgical bleeding concerning for missed or inadequately addressed injury. A survey from the Western Trauma Association found the majority of its members wait approximately 24 hours 
for first return to the operating room [2]. Once all injuries have been definitively addressed the abdomen should be closed. The American Association for the Surgery of Trauma studied factors contributing to primary closure and found that those who achieved primary closure were more likely to be women, had lower peak airway pressures, an injury severity score $<15$, lower lactate levels, higher $\mathrm{pH}$, and lower blood loss. Those who were closed primarily also had fewer EC fistula, abscesses, ICU and ventilator days. Interestingly the volume of crystalloid given was $<5 \mathrm{~L}$ and did not vary between groups. Overall closure rate was $59.1 \%$ [76].

A review of the literature suggest a bimodal distribution of patients with TAC, the first are able to be closed within 4-7 days and achieve a high rate of primary closure, the second group have a delayed (20-40 days) and much lower overall rate of closure [77]. Thus, if unable to close the abdomen within 7 days a progressive closure device may be necessary. This can be achieved using multiple devices, one of the most common; the Wittman patch is sewn to the fascial edges and prevents further loss of domain while slowly bringing the fascial edges together. Multiple studies of the Wittman patch have demonstrated a 78-93\% fascial closure rate [55-58]. Modifications of the VAC closure with the addition of retention type sutures in the skin and fascia can significantly increase rates of primary closure to $88-100 \%[38,39]$, compared to serial VAC changes which have a primary closure rate of $31 \%$ [42]. Absorbable mesh can be used similarly to the Wittman patch, stitching it to the fascia and slowly bringing the fascial edges together during serial returns to the operating room as the visceral edema resolves with primary closure rates of $22-38 \%$ [42,50,51].

If unable to close the fascial defect with progressive closure techniques, the operative plan must shift gears to one of an expectant hernia (Figure 1). Patients with residual fascial defects should be covered with split thickness skin grafting once the viscera are fixed and granulation tissue is sufficient $[42,50,51]$. Because of the high risk of infection, synthetic graft material should be removed prior to skin grafting [49].

Formal reconstruction of the ventral hernia should be deferred until after the patient has fully recovered and is ready for another large operation. Timing of the definitive repair is not well studied, Jernigan et al., recommend 6-12 months but no longer as they found less need for prosthetic bridging and lower recurrence rate due to more tension free repair in patients operated on earlier than 12 months. Component separation may be required to span the defect; there are multiple methods for this procedure with good outcomes reported [51]. In clean fields, synthetic mesh may be utilized as a bridge if the patient cannot be closed primarily with or without component separation. Another option to close the

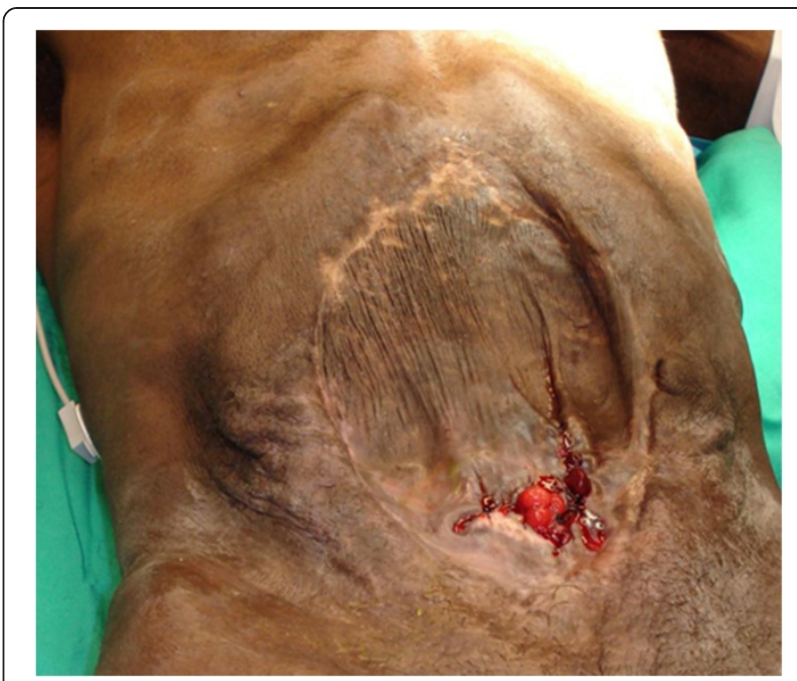

Figure 1 Example of a patient's abdominal wall with planned ventral hernia after vicryl mesh placement and split thickness skin grafting.

fascial defect is to use a biologic material, such as human acellular dermal matrix (HADM). This has the benefit of being an option in a contaminated or infected field. As described by Scott et al., the HADM is fixed transfascially with $2-3 \mathrm{~cm}$ of underlay, with multiple pieces stitched together if necessary. The repair should be taut to reduce laxity. If the skin edges can be mobilized and closed, closed suction drains are left to manage the dead space; otherwise a non-adherent dressing is placed over the HADM and a negative pressure dressing is applied [78]. Two series looked at this method [78,79] and reported good outcomes, but with concern for recurrent hernia and eventration.

\section{Recommendations \\ We recommend}

1. Damage control laparotomy for trauma or acute general surgical patients under physiologic stress including; acidosis, hypothermia, hypocoagulable state, prolonged hypotension. Also, those requiring a "second-look" after ischemic or embolic events or intra-abdominal infections which may need additional debridement such as necrotizing pancreatitis.

2. Initial abdominal closure should employ a negative pressure dressing such as the "vacuum pack" method or its commercially available alternative.

3. After 5-7 days if the abdomen cannot be closed convert to the use of a bridging device which progressively brings the fascia together such as the Wittman patch or modified V.A.C.@. 


\section{We suggest}

1. Unless otherwise contraindicated enteral nutrition should be started early.

2. In the absence of definite indication, prophylactic antibiotics should be limited to 24 hours.

3. Formal reconstruction if necessary should be delayed 6-12 months and tempered with a planned ventral hernia.

\section{Abbreviations}

DCL: Damage control laparotomy; TAC: Temporary abdominal closure; ACS: Abdominal compartment syndrome; ICU: Intensive care unit; RCT: Randomized controlled trials; SBP: Systolic blood pressure; ED: Emergency department; PRBCs: Packed red blood cells; IAP: Intraabdominal pressure; IAH: Intra-abdominal hypertension; EC fistula: Enterocutaneous fistula; VAC: Vacuum assisted closure; VP: Vacuum pack; PPE: Polypropylene; ePTFE: expanded polytetrafluoroethylene; MTP: of massive transfusion protocols; NMB: neuromuscular blockade; HADM: Human acellular dermal matrix

\section{Competing interests}

The Authors all declare that they have no competing interests.

\section{Authors' contributions}

All authors helped to draft the manuscript. All authors read and approved the final manuscript.

Received: 9 December 2013 Accepted: 10 December 2013

Published: 17 December 2013

\section{References}

1. Wyrzykowski AD, Feliciano DV: Trauma damage control. In Trauma. 6th edition. Edited by Feliciano DV, Mattox KL, Moore EE. United States of America: The McGraw-Hill Companies, Inc; 2008:851-870.

2. Campbell A, Chang M, Fabian T, Franz M, Kaplan M, Moore F, Reed RL, Scott $B$, Silverman R: Management of the open abdomen: from initial operation to definitive closure. Am Surg 2009, 75:S1-S22.

3. Barker DE, Green JM, Maxwell RA, Smith PW, Mejia VA, Dart BW, Cofer JB, Roe SM, Burns RP: Experience with vacuum-pack temporary abdominal wound closure in 258 trauma and general and vascular surgical patients. J Am Coll Surg 2007, 204:784-792. discussion 792-783.

4. Aydin C, Aytekin FO, Yenisey C, Kabay B, Erdem E, Kocbil G, Tekin K: The effect of different temporary abdominal closure techniques on fascial wound healing and postoperative adhesions in experimental secondary peritonitis. Langenbecks Arch Surg 2008, 393:67-73.

5. Stone HH, Strom PR, Mullins RJ: Management of the major coagulopathy with onset during laparotomy. Ann Surg 1983, 197:532-535.

6. Sharp KW, Locicero RJ: Abdominal packing for surgically uncontrollable hemorrhage. Ann Surg 1992, 215:467-474. discussion 474-465.

7. Hirshberg A, Wall MJ Jr, Mattox KL: Planned reoperation for trauma: a two year experience with 124 consecutive patients. J Trauma 1994, 37:365-369.

8. Asensio JA, McDuffie L, Petrone P, Roldan G, Forno W, Gambaro E, Salim A, Demetriades D, Murray J, Velmahos G, et al: Reliable variables in the exsanguinated patient which indicate damage control and predict outcome. Am J Surg 2001, 182:743-751.

9. Garrison JR, Richardson JD, Hilakos AS, Spain DA, Wilson MA, Miller FB, Fulton RL: Predicting the need to pack early for severe intra-abdominal hemorrhage. J Trauma 1996, 40:923-927. discussion 927-929.

10. Offner PJ, de Souza AL, Moore EE, Biffl WL, Franciose RJ, Johnson JL, Burch $\mathrm{JM}$ : Avoidance of abdominal compartment syndrome in damage-control laparotomy after trauma. Arch Surg 2001, 136:676-681.

11. Johnson JW, Gracias VH, Schwab CW, Reilly PM, Kauder DR, Shapiro MB, Dabrowski GP, Rotondo MF: Evolution in damage control for exsanguinating penetrating abdominal injury. J Trauma 2001, 51:261-269. discussion 269-271.

12. Diaz JJ Jr, Cullinane DC, Dutton WD, Jerome R, Bagdonas R, Bilaniuk JW, Collier BR, Como JJ, Cumming J, Griffen M, et al: The management of the open abdomen in trauma and emergency general surgery: part 1-damage control. J Trauma 2010, 68:1425-1438.

13. Cheatham ML, Malbrain ML, Kirkpatrick A, Sugrue M, Parr M, De Waele J, Balogh Z, Leppaniemi A, Olvera C, Ivatury R, et al: Results from the international conference of experts on intra-abdominal hypertension and abdominal compartment syndrome. II. Recommendations. Intensive Care Med 2007, 33:951-962.

14. Raeburn CD, Moore EE, Biffl WL, Johnson JL, Meldrum DR, Offner PJ, Franciose RJ, Burch JM: The abdominal compartment syndrome is a morbid complication of postinjury damage control surgery. Am J Surg 2001, 182:542-546

15. Oelschlager BK, Boyle EM Jr, Johansen K, Meissner MH: Delayed abdominal closure in the management of ruptured abdominal aortic aneurysms. Am J Surg 1997, 173:411-415.

16. Rasmussen TE, Hallett JW Jr, Noel AA, Jenkins G, Bower TC, Cherry KJ Jr, Panneton JM, Gloviczki P: Early abdominal closure with mesh reduces multiple organ failure after ruptured abdominal aortic aneurysm repair: guidelines from a 10-year case-control study. J Vasc Surg 2002, 35:246-253.

17. Malbrain ML, Cheatham ML, Kirkpatrick A, Sugrue M, Parr M, De Waele J, Balogh Z, Leppaniemi A, Olvera C, Ivatury R, et al: Results from the international conference of experts on intra-abdominal hypertension and abdominal compartment syndrome. I. Definitions. Intensive Care Med 2006, 32:1722-1732.

18. Garcia-Sabrido JL, Tallado JM, Christou NV, Polo JR, Valdecantos E: Treatment of severe intra-abdominal sepsis and/or necrotic foci by an 'open-abdomen' approach. Zipper and zipper-mesh techniques. Arch Surg 1988, 123:152-156.

19. Wittmann DH, Aprahamian C, Bergstein JM: Etappenlavage: advanced diffuse peritonitis managed by planned multiple laparotomies utilizing zippers, slide fastener, and velcro analogue for temporary abdominal closure. World J Surg 1990, 14:218-226.

20. Ozguc H, Yilmazlar T, Gurluler E, Ozen Y, Korun N, Zorluoglu A: Staged abdominal repair in the treatment of intra-abdominal infection: analysis of 102 patients. J Gastrointest Surg 2003, 7:646-651.

21. Besselink MG, de Bruijn MT, Rutten JP, Boermeester MA, Hofker HS, Gooszen HG Surgical intervention in patients with necrotizing pancreatitis. Br J Surg 2006, 93:593-599.

22. Kafka-Ritsch R, Birkfellner F, Perathoner A, Raab H, Nehoda H, Pratschke J, Zitt M: Damage control surgery with abdominal vacuum and delayed bowel reconstruction in patients with perforated diverticulitis Hinchey III/IV. J Gastrointest Surg 2012, 16:1915-1922.

23. Kaminsky O, Yampolski I, Aranovich D, Gnessin E, Greif F: Does a secondlook operation improve survival in patients with peritonitis due to acute mesenteric ischemia? A five-year retrospective experience. World J Surg 2005, 29:645-648.

24. Arhinful E, Jenkins D, Schiller HJ, Cullinane DC, Smoot DL, Zielinski MD: Outcomes of damage control laparotomy with open abdomen management in the octogenarian population. J Trauma 2011, 70:616-621.

25. Subramanian A, Balentine C, Palacio CH, Sansgiry S, Berger DH, Awad SS: Outcomes of damage-control celiotomy in elderly nontrauma patients with intra-abdominal catastrophes. Am J Surg 2010, 200:783-788. discussion 788-789.

26. Hatch QM, Osterhout LM, Podbielski J, Kozar RA, Wade CE, Holcomb JB, Cotton BA: Impact of closure at the first take back: complication burden and potential overutilization of damage control laparotomy. J Trauma 2011, 71:1503-1511

27. Martin MJ, Hatch Q, Cotton B, Holcomb J: The use of temporary abdominal closure in low-risk trauma patients: Helpful or harmful? J Trauma Acute Care Surg 2012, 72:601-606. discussion 606-608.

28. Balogh Z, McKinley BA, Cocanour CS, Kozar RA, Holcomb JB, Ware DN, Moore FA: Secondary abdominal compartment syndrome is an elusive early complication of traumatic shock resuscitation. Am J Surg 2002, 184:538-543. discussion 543-534.

29. Balogh Z, McKinley BA, Holcomb JB, Miller CC, Cocanour CS, Kozar RA, Valdivia A, Ware DN, Moore FA: Both primary and secondary abdominal compartment syndrome can be predicted early and are harbingers of multiple organ failure. J Trauma 2003, 54:848-859. discussion 859-861.

30. Rutherford EJ, Skeete DA, Brasel KJ: Management of the patient with an open abdomen: techniques in temporary and definitive closure. Curr Probl Surg 2004, 41:815-876. 
31. Kirshtein B, Roy-Shapira A, Lantsberg L, Mizrahi S: Use of the "Bogota bag" for temporary abdominal closure in patients with secondary peritonitis. Am Surg 2007, 73:249-252.

32. Doyon A, Devroede G, Viens D, Saito S, Rioux A, Echave V, Sauve M, Martin M, Poisson J: A simple, inexpensive, life-saving way to perform iterative laparotomy in patients with severe intra-abdominal sepsis. Colorectal Dis 2001, 3:115-121.

33. Tremblay LN, Feliciano DV, Schmidt J, Cava RA, Tchorz KM, Ingram WL, Salomone JP, Nicholas JM, Rozycki GS: Skin only or silo closure in the critically ill patient with an open abdomen. Am J Surg 2001, 182:670-675.

34. Brox-Jimenez A, Ruiz-Luque V, Torres-Arcos C, Parra-Membrives $P$, Diaz-Gomez D, Gomez-Bujedo L, Marquez-Munoz M: Experience with the Bogota bag technique for temporary abdominal closure. Cirugia Espanola 2007, 82:150-154.

35. Foy HM, Nathens AB, Maser B, Mathur S, Jurkovich GJ: Reinforced silicone elastomer sheeting, an improved method of temporary abdominal closure in damage control laparotomy. Am J Surg 2003, 185:498-501.

36. Howdieshell TR, Proctor CD, Sternberg E, Cue Jl, Mondy JS, Hawkins ML: Temporary abdominal closure followed by definitive abdominal wall reconstruction of the open abdomen. Am J Surg 2004, 188:301-306.

37. Brock WB, Barker DE, Burns RP: Temporary closure of open abdominal wounds: The vacuum pack. Am Surg 1995, 61:30-35.

38. Cothren CC, Moore EE, Johnson JL, Moore JB, Burch JM: One hundred percent fascial approximation with sequential abdominal closure of the open abdomen. Am J Surg 2006, 192:238-242.

39. Miller PR, Meredith JW, Johnson JC, Chang MC: Prospective evaluation of vacuum-assisted fascial closure after open abdomen: Planned ventral hernia rate is substantially reduced. Ann Surg 2004, 239:608-614. discussion 614-606.

40. Suliburk JW, Ware DN, Balogh Z, McKinley BA, Cocanour CS, Kozar RA, Moore FA, Ivatury RR: Vacuum-assisted wound closure achieves early fascial closure of open abdomens after severe trauma. J Trauma 2003, 55:1155-1160. discussion 1160-1151.

41. Barker DE, Kaufman HJ, Smith LA, Ciraulo DL, Richart CL, Burns RP: Vacuum pack technique of temporary abdominal closure: A 7-year experience with 112 patients. J Trauma 2000, 48:201-206. discussion 206-207.

42. Bee TK, Croce MA, Magnotti LJ, Zarzaur BL, Maish GO 3rd, Minard G, Schroeppel TJ, Fabian TC: Temporary abdominal closure techniques: a prospective randomized trial comparing polyglactin 910 mesh and vacuum-assisted closure. J Trauma 2008, 65:337-342. discussion 342-334.

43. Smith LA, Barker DE, Chase CW, Somberg LB, Brock WB, Burns RP: Vacuum pack technique of temporary abdominal closure: A four-year experience. Am Surg 1997, 63:1102-1107. discussion 1107-1108.

44. Teixeira PG, Salim A, Inaba K, Brown C, Browder T, Margulies D, Demetriades D: A prospective look at the current state of open abdomens. Am Surg 2008, 74:891-897.

45. Miller PR, Thompson JT, Faler BJ, Meredith JW, Chang MC: Late fascial closure in lieu of ventral hernia: The next step in open abdomen management. J Trauma 2002, 53:843-849.

46. Cheatham ML, Demetriades D, Fabian TC, Kaplan MJ, Miles WS, Schreiber MA, Holcomb JB, Bochicchio G, Sarani B, Rotondo MF: Prospective study examining clinical outcomes associated with a negative pressure wound therapy system and Barker's vacuum packing technique. World I Surg 2013, 37:2018-2030.

47. Acosta S, Bjarnason T, Petersson U, Palsson B, Wanhainen A, Svensson M Djavani K, Bjorck M: Multicentre prospective study of fascial closure rate after open abdomen with vacuum and mesh-mediated fascial traction. Br J Surg 2011, 98:735-743.

48. Vertrees A, Kellicut D, Ottman S, Peoples G, Shriver C: Early definitive abdominal closure using serial closure technique on injured soldiers returning from Afghanistan and Iraq. J Am Coll Surg 2006, 202:762-772.

49. Vertrees A, Greer L, Pickett C, Nelson J, Wakefield M, Stojadinovic A, Shriver $C$ : Modern management of complex open abdominal wounds of war: a 5-year experience. J Am Coll Surg 2008, 207:801-809.

50. Mayberry JC, Burgess EA, Goldman RK, Pearson TE, Brand D, Mullins RJ: Enterocutaneous fistula and ventral hernia after absorbable mesh prosthesis closure for trauma: the plain truth. J Trauma 2004, 57:157-162. discussion 163-153.

51. Jernigan TW, Fabian TC, Croce MA, Moore N, Pritchard FE, Minard G, Bee TK: Staged management of giant abdominal wall defects: acute and long-term results. Ann Surg 2003, 238:349-355. discussion 355-347.
52. Brandt CP, McHenry CR, Jacobs DG, Piotrowski JJ, Priebe PP: Polypropylene mesh closure after emergency laparotomy: morbidity and outcome. Surgery 1995, 118:736-740. discussion 740-731.

53. Tons C, Schachtrupp A, Rau M, Mumme T, Schumpelick V: Abdominal compartment syndrome: prevention and treatment. Der Chirurg; Zeitschrift fur alle Gebiete der operativen Medizen 2000, 71:918-926.

54. Sugrue M, Jones F, Janjua KJ, Deane SA, Bristow P, Hillman K: Temporary abdominal closure: a prospective evaluation of its effects on renal and respiratory physiology. J Trauma 1998, 45:914-921.

55. Weinberg JA, George RL, Griffin RL, Stewart AH, Reiff DA, Kerby JD, Melton SM, Rue LW 3rd: Closing the open abdomen: improved success with Wittmann Patch staged abdominal closure. J Trauma 2008, 65:345-348.

56. Tieu BH, Cho SD, Luem N, Riha G, Mayberry J, Schreiber MA: The use of the Wittmann Patch facilitates a high rate of fascial closure in severely injured trauma patients and critically ill emergency surgery patients. J Trauma 2008, 65:865-870

57. Wittmann DH: Staged abdominal repair: Development and current practice of an advanced operative technique for diffuse suppurative peritonitis. Acta Chirurgica Austriaca 2000, 32:171-178.

58. Hadeed JG, Staman GW, Sariol HS, Kumar S, Ross SE: Delayed primary closure in damage control laparotomy: The value of the Wittmann patch. Am Surg 2007, 73:10-12.

59. Schnuriger B, Inaba K, Wu T, Eberle BM, Belzberg H, Demetriades D: Crystalloids after primary colon resection and anastomosis at initial trauma laparotomy: Excessive volumes are associated with anastomotic leakage. J Trauma 2011, 70:603-610.

60. Cotton BA, Guy JS, Morris JA Jr, Abumrad NN: The cellular, metabolic, and systemic consequences of aggressive fluid resuscitation strategies. Shock 2006, 26:115-121.

61. Cotton BA, Gunter OL, Isbell J, Au BK, Robertson AM, Morris JA Jr, St Jacques $P$ : Damage control hematology: the impact of a trauma exsanguination protocol on survival and blood product utilization. J Trauma 2008, 64:1177-1182. discussion 1182-1173.

62. Holcomb JB, Jenkins D, Rhee P, Johannigman J, Mahoney P, Mehta S, Cox ED, Gehrke MJ, Beilman GJ, Schreiber M, et al: Damage control resuscitation: directly addressing the early coagulopathy of trauma. J Trauma 2007, 62:307-310.

63. Holcomb JB, Wade CE, Michalek JE, Chisholm GB, Zarzabal LA, Schreiber MA Gonzalez EA, Pomper GJ, Perkins JG, Spinella PC, et al: Increased plasma and platelet to red blood cell ratios improves outcome in 466 massively transfused civilian trauma patients. Ann Surg 2008, 248:447-458.

64. Lustenberger T, Frischknecht A, Bruesch M, Keel MJ: Blood component ratios in massively transfused, blunt trauma patients-a time-dependent covariate analysis. J Trauma 2011, 71:1144-1150. discussion 1150-1141.

65. Wafaisade A, Maegele $M$, Lefering $R$, Braun M, Peiniger $S$, Neugebauer $E_{1}$ Bouillon B: High plasma to red blood cell ratios are associated with lower mortality rates in patients receiving multiple transfusion $(4</=$ red blood cell units $<10$ ) during acute trauma resuscitation. J Trauma 2011, 70:81-88. discussion 88-89.

66. Cotton BA, Au BK, Nunez TC, Gunter OL, Robertson AM, Young PP: Predefined massive transfusion protocols are associated with a reduction in organ failure and postinjury complications. J Trauma 2009, 66:41-48. discussion 48-49.

67. Harvin JA, Mims MM, Duchesne JC, Cox CS Jr, Wade CE, Holcomb JB, Cotton BA: Chasing 100\%: the use of hypertonic saline to improve early, primary fascial closure after damage control laparotomy. Trauma Acute Care Surg 2013, 74:426-430. discussion 431-422.

68. Fullen WD, Hunt J, Altemeier WA: Prophylactic antibiotics in penetrating wounds of the abdomen. J Trauma 1972, 12:282-289.

69. Goldberg SR, Anand RJ, Como JJ, Dechert T, Dente C, Luchette FA, Ivatury RR, Duane TM: Prophylactic antibiotic use in penetrating abdominal trauma: An Eastern association for the surgery of trauma practice management guideline. Trauma Acute Care Surg 2012, 73:S321-\$325.

70. Abouassaly CT, Dutton WD, Zaydfudim V, Dossett LA, Nunez TC, Fleming SB, Cotton BA: Postoperative neuromuscular blocker use is associated with higher primary fascial closure rates after damage control laparotomy. J Trauma 2010, 69:557-561

71. Webb LH, Patel MB, Dortch MJ, Miller RS, Gunter OL, Collier BR: Use of a furosemide drip does not improve earlier primary fascial closure in the open abdomen. J Emerg Trauma Shock 2012, 5:126-130. 
72. Collier B, Guillamondegui O, Cotton B, Donahue R, Conrad A, Groh K, Richman J, Vogel T, Miller R, Diaz J Jr: Feeding the open abdomen. JPEN J Parenter Enteral Nutr 2007, 31:410-415.

73. Burlew CC, Moore EE, Cuschieri J, Jurkovich GJ, Codner P, Nirula R, Millar D, Cohen MJ, Kutcher ME, Haan J, et al: Who should we feed? Western trauma association multi-institutional study of enteral nutrition in the open abdomen after injury. Trauma Acute Care Surg 2012, 73:1380-1387. discussion 1387-1388.

74. Byrnes MC, Reicks P, Irwin E: Early enteral nutrition can be successfully implemented in trauma patients with an "open abdomen". Am J Surg 2010, 199:359-362. discussion 363.

75. Dissanaike S, Pham T, Shalhub S, Warner K, Hennessy L, Moore EE, Maier RV, O'Keefe GE, Cuschieri J: Effect of immediate enteral feeding on trauma patients with an open abdomen: protection from nosocomial infections. J Am Coll Surg 2008, 207:690-697.

76. Dubose JJ, Scalea TM, Holcomb JB, Shrestha B, Okoye O, Inaba K, Bee TK, Fabian TC, Whelan J, Ivatury RR: Open abdominal management after damage-control laparotomy for trauma: a prospective observational American association for the surgery of trauma multicenter study. Trauma Acute Care Surg 2013, 74:113-120. discussion 1120-1122.

77. Regner JL, Kobayashi L, Coimbra R: Surgical strategies for management of the open abdomen. Am J Surg 2012, 36:497-510.

78. Scott BG, Welsh FJ, Pham HQ, Carrick MM, Liscum KR, Granchi TS, Wall MJ Jr, Mattox KL, Hirshberg A: Early aggressive closure of the open abdomen. J Trauma 2006, 60:17-22.

79. de Moya MA, Dunham M, Inaba K, Bahouth H, Alam HB, Sultan B, Namias N: Long-term outcome of acellular dermal matrix when used for large traumatic open abdomen. J Trauma 2008, 65:349-353.

doi:10.1186/1749-7922-8-53

Cite this article as: Godat et al: Abdominal damage control surgery and reconstruction: world society of emergency surgery position paper.

World Journal of Emergency Surgery 2013 8:53.

\section{Submit your next manuscript to BioMed Central and take full advantage of:}

- Convenient online submission

- Thorough peer review

- No space constraints or color figure charges

- Immediate publication on acceptance

- Inclusion in PubMed, CAS, Scopus and Google Scholar

- Research which is freely available for redistribution 